\title{
Cek 2
}

by Turnitin Check

Submission date: 07-Nov-2020 05:35AM (UTC+0700)

Submission ID: 1438473114

File name: 10-published-To_Embrace_and_Be_Embraced.pdf (357.01K)

Word count: 7641

Character count: 40110 


\title{
2 \\ TO EMBRACE AND BE EMBRACED: SCHOOL PELA IN POST-CONFLICT AMBON
}

\author{
Rachel Iwamony, Steve GaSPERSZ \& Nancy Souisa
}

2

\begin{abstract}
This article focuses on the pela between SMP Negeri 9 Lateri and SMP Negeri 4 Salahutu. It is based on field research method, that is observation, interview and focus group discussion. This research finds that it is through religious celebrations and other programs students are able to cross religious boundaries. The schools connected with pela provide a space for the students to share their stories, to understand the structure of power, to know each other's burdens, and to share joy and happiness. Collective activities help Christian and Muslim students heal their historic scars caused by the religious conflict. Further, they learn that religion should not separate people or destroy human life. At the same time, these activities also affect the relations among teachers and staffs. On a smaller scale, it brings a more peaceful relationship between Muslim and Christian students, teachers and staffs. On a larger scale, it places pela school relationships as a form of inclusive religious education, based on local practices, which has a significant impact to build the post-conflict Maluku society.
\end{abstract}

\section{Keywords}

Pela, peace religious education, social conflict, cultural approach, Ambon

\section{Authors}

Rachel Iwamony is the director of the Graduate Program of Universitas Kristen Indonesia Maluku (UKIM). She teaches theology of religions and Christian Spirituality.

Steve Gaspersz is a lecturer at Graduate Program of UKIM, teaching Religious Studies, Contextual Theology and Social Research Methods; he also serves as Vice Rector for Student Affairs at UKIM.

Nancy Souisa is a lecturer at the Theology Faculty of UKIM and the head of the Department of Christian Education, also teaching feminism, gender and theology.

Studies in Interreligious Dialogue 29/1, 83-101 doi: 10.2143/SID.29.1.3286456

(c) 2019 by Peeters. All rights reserved. 


\section{INTRODUCTION}

After the 1999-2005 conflict in Ambon, people generally live in separation based primarily on their religious affiliation. However, such separation of religious communities is hardly a new phenomenon. It has long been a part of the Ambonese social life since the arrival of Islam and Christianity in Maluku archipelago and the influence of Dutch colonial policy. This religious segregation was further intensified by the Indonesian national government intervention during the conflict. By knowing where someone resides, we can know one's religions. Someone who lives in Liang or Kebun Cengkeh, for instance, is likely to be a Muslim; whereas someone who lives in Waai or Lateri is a Christian.

The impact of this situation for the young generations, especially students at elementary, junior high, and senior high schools, who live in homogenous areas, such as Lateri (Christian) and Liang Salahutu (Islam), is that they do not have the experience of meeting and joining in activities with their peers from other religions. The lack of contact continues when they enroll in religiously-based higher education, such as the State Islamic Institute (Institut Agama Islam Negeri - IAIN) and the State Christian Institute (Institut Agama Kristen Negeri - IAKN), which exclusively admits students based on their religious affiliation.

The situation is quite different in other universities such as Indonesian Maluku Christian University (UKIM) and Pattimura University. UKIM is a private Christian university with an open policy; admitting students and hiring lecturers from different cultural and religious backgrounds. Meanwhile, Pattimura University (Unpatti) is the only state university in Maluku that has students and lecturers from every region of Indonesia. UKIM offers a Christian Ethics course for all students while providing space for students from other religions to conduct their own prayers and worships. Unpatti keeps its character as the state university for all religions but offers no courses on religion.

In this context, one acknowledges that the establishment of school pela offers a new way to overcome religiously-based segregation and social distrust among people. These bonds create the space for students, teachers and staffs to meet with each other, to know each other's religion and to gain awareness of the importance of knowing each other. 


\section{The Story of PELA}

Pela is a Maluku local custom which was performed to overcome crisis situations such as local war between villages or help villages recovering from a natural disaster, in which, one village received assistance from another village. In each situation, villages declared themselves as brothers and sisters. By doing pela, they recognized some basics obligations between each other. They have to help each other, take care of or protect each other. In some pela relationships, especially the ones called pela darah (blood pela), members of those villages are prohibited to marry each other, even if they have no familial relationship (Bartels, 1977:145). Beside this type of pela, there are some other types, such as pela batu karang (rock pela), pela gandong (womb pela), pela tampa siri (betel-box pela). Generally, pela batu karang is another term used to refer to pela darah (blo 1 pela) or pela keras (hard pela). Concerning pela batu karang, Frank Cooley writes:

This type of pela was established by a sumpah-djanji, 'oath-promise', between the leaders of the two parties of ancestors, involving the mixing blood drawn from the fingers of the chiefs in a glass of locally made liquor, the dipping of the tips of weapon in it then the drinking of it by all notable present, which act sealed in a most binding way the oath to be brothers for all time. As blood brothers, intermarriage between the pela partners is strictly forbidden. They are obligated to come to one another's help in time of warfare or any other crisis. They are obligated to render mutual assistance in all matters and all time supply whatever the pela-partner requests (Cooley, 1962:71-72).

Pela gandong is a term referring to $a$ gandong ${ }^{1}$ relationship. According Dieter Bartels,

While this type of pela is not considered genuine, it is just as 'hard' as a pela keras. Normally, it has all features of the pela keras category, including the oath and exogamy. Exactly the same mutual obligation and sanction for transgressing the rules of pela apply, and emotionally villages tied in a pela gandong feel just as strongly about the relationship as people linked in a pela keras. For all intents and purposes the two types of pela are identical except in their origins (Bartels, 1978:184-185).

After the social conflict in Ambon, villages involved in a pela relationship 11 fuse to use the term pela. Rather, they prefer the word gandong only because in their point of view, a pela is based on an oath or a pact

\footnotetext{
${ }^{1}$ Gandong is a Mollucans word that literally meanst "womb."
} 
which was prec1 1led by either a war or a natural disaster. Meanwhile, they understand their alliance as one based on blood relation or fact that they have common ancestors (Iwamony, 2010:67).

\section{Cooley explained also about pela tampa siri:}

Pela tampa siri or betel-box pela taking its name from traditional custom of passing the betel box, containing the materials needed for chewing betel nut, to all guests, much as cigarettes and drinks are passed around now. It is a soft pela, that is, it was not established by an oath and does not carry the strict fixed obligation noted above. Intermarriage is not necessarily taboo, although in some cases it might be. The friendly relation established between two or more villages bound in a pela tampa siri involves mutual assistance in public works, especially the erection of public building such as Baileo, church, mosque, or school (Cooley, 1962:72).

This explanation on the three types of pela, helps us discover that the school pela between the Junior High Schools which is the focus of this research is the mixed form of pela keras and pela tampa siri.

Pela becomes an important societal system in Central Maluku Area. It has its philosophy, ritual and mechanism. The core philosophy of pela is to embrace each other and to live in mutual assistance. Generally, the ritual of a pela must be performed by at least two parties who are committed to live in brotherhood-sisterhood relationship. In the ritual of pela keras and pela gandong, drinking mixed blood and taking an oath are very important elements. This ritual binds two or more villages into a special sibling relationship. Because of this brotherhood-sisterhood relation, the pela became an important component of public ethics in Maluku society (Ruhulessin, 2005). People have reflected on humankind and its relation to one another. They find that every event has its own potential for the future. One of the ways of moving forward to the future is through a respect for the past experiences. Another reflection is that pela relationship has an influence for public ethics. People produced for themselves a kind of moral attitude in society. Then, the term of pela became an umbrella for a kind of relationship among villages.

\section{The School PELA}

This article is based on field research conducted by the authors of this article on two schools in Ambon in October 2017 and in February - March 2018. The research conducted interviews and a participatory 
observation. Interviews were conducted with 7 teachers: two Muslim teachers and 5 Christian teachers. Moreover, we also conducted a Focus Group Discussion with 20 students: 10 Muslims and 10 Christians, aged 14 to 15 years old. The data was collected through those methods and framed by an interpretive analysis that looks into the meaning of each datum. By interpretive analysis, researchers try to understand the meaning of words, actions, and events in their specific context, both as insiders and outsiders. A researcher will get false or misleading data if $s /$ he conducts research only as an outsider without trying to learn as an insider.

The two schools that we observed are: Sekolah Menengah Pertama Negeri (State Junior High School; from now on will be written SMP Negeri) 4 Salahutu and SMP Negeri 9 Lateri. Both are located on Ambon Island. On the one hand, SMP Negeri 4 Salahutu is in the eastern part of the island, in Liang, a Muslim-majority village. On the other hand, SMP Negeri 9 Lateri is located close to the centre of the island, in Lateri, which is predominantly Christian. Unsurprisingly, students of SMP Negeri 4 Salahutu are Muslims and SMP Negeri 9 Lateri are Christians, except for approximately eleven Muslims whose parents are members of the police or military currently stationed nearby. In other words, although these two schools belong to the state, the students who enroll reflect the community where the schools are established, and are thus just as religiously homogeneous.

In June 2013, teachers, students and staff of SMP Negeri 4 Salahutu and SMP Negeri 9 Lateri conducted the ritual of declaring themselves pela schools. In that ritual, held at SMP Negeri 9 Lateri, these schools made a covenant and swore that "as brothers and sisters, these two junior high schools are obligated to help each other, protect each other, and enact solidarity in their educational activities". They continued the ritual of this covenant by performing a kapata (traditional song) that "siapa bale batu, batu bale dia" meaning that whosoever betrays this stone, as the covenant is referred to, will be betrayed by it. The schools were represented by religious education teachers and by the leaders of the student government.

However, according to the two religious education teachers, Muhammad Laga and Mrs. Henny Liklikwatil, establishing this pela between the two schools required a long effort. "When we started this school pela, everyone doubted us - students, parents, even teachers". ${ }^{2}$

\footnotetext{
${ }^{2}$ Interview Mrs. Heny Liklikwatil, a teacher who teaches Christian Religious Education.
} 
"Everyone doubted because these two schools are located in religiously homogeneous communities and are a great distance apart. We were aware that we were taking a big risk by conducting this pela relationship. Before conducting the pela, we first planned a camping trip to Suli Beach with (Christian) SMP Negeri 9 Lateri as the host. According to our planning, we were going to spend the night there. Unfortunately, parents of all students at Liang refused to allow their children to sleep over and would only give permission for a day trip. Surprisingly, when we were packing up to go home, many students from SMP Negeri 4 asked to do it again. We, teachers saw that as a positive indication for conducting the school pela. Finally, as has been stated above, in June 2013, this school pela was launched. People from both Lateri and Liang do not doubt anymore. They support every program of the school pela." 3

Since then, the pela schools have continued to conduct several kinds of activities together. Pramuka is a kind of outdoor activities or scouting program for boys and girls found throughout Indone $2 \mathrm{a}$. The pela schools hold activities like these together twice a year, with SMP Negeri 9 Lateri and SMP Negeri 4 Salahutu alternating as hosts. When they go for camping trips, both Muslim and Christian students prepare foods and eat together. In order to make sure that the foods are halal, however, SMP Negeri 4 Salahutu would be in charge of buying the foods. Furthermore, the empowerment program offers activities for both students and teachers. Students join in leadership workshops and practice debating in English. The teachers would meet with their counterparts to discuss the content and methods for teaching their shared subject. In addition, SMP Negeri 9 Lateri invites the Islamic Religious Education teacher from SMP Negeri 4 Salahutu to teach several Muslim students there because they do not have an instructor to teach that subject. Finally, students come together once a year for "sports and arts week" (Pekan Olah Raga dan Seni or PORSENI). There are musical and dance performances, poetry readings, soccer and volleyball matches, and so on.

Fostering the mutual understanding of religious differences and commonalities, through discussion and participation in their respective religious festivals are necessary. Students and teachers from the pela schools gather twice a year to visit each other during the celebration of important festivals. For instance, students from SMP Negeri 4 would participate in Christmas celebrations at SMP Negeri 9 and students from SMP Negeri 9 would participate in Halal Bihalal (Islamic gathering), conducted on

\footnotetext{
${ }^{3}$ Interview Mr. Muhammad Laga (His nickname is Cecep), a teacher who teaches Islam Religious Education.
} 
the seventh day after Idul Fitri, the most important Islamic holiday of the year, marking the end of the Ramadhan month of fasting. According to the principal of SMP Negeri 9, when they celebrate Idul Fitri, teachers at the Christian SMP Negeri 9 would serve as the organizers and during Christmas, teachers from Muslim SMP Negeri 4 would organize the celebration. In the Christmas celebrations, Muslim students participate by singing Christmas songs and also reading Christmas poems. According to the Christian education teacher at SMP Negeri 9, in 2015, a student from SMP Negeri 4 Salahutu wrote a beautiful Christmas poem and she read it at the celebration. At the Halal Bihalal, students from SMP Negeri 9 participate by singing Qasidah songs. The female Christian students also dress like the Muslimah students, in long skirts and sleeves and covering their heads with veils.

In the Focus Group Discussions, students who have had the experience of celebrating other religious celebrations shared their impression. A Christian student said "When I wore long skirts and veil, I felt I could not walk freely. I can imagine how hard it is for a Muslim woman to walk". ${ }^{4}$ Another Christian student said that "taking part in Halal Bihalal and singing Qasidah songs we learnt that Muslims' song is different to our songs, but we have to respect to each other". ${ }^{5}$ Recognizing their religious differences and awareness of respecting each other was also a Muslim student impression. A Muslim student said, "It was my first experience to join a Christmas celebration at SMP Negeri 9 Lateri, our pela schools. I enjoy it, but it does not change my belief as a Muslim". ${ }^{6}$

\section{Creating Space and Chance for Meeting and Conversation}

The first motivation for performing this pela between the two schools is to bridge the social separation between Muslims and Christians. Residential segregation intensified after the conflict of 1999-2004, so now Christians and Muslims live in religiously homogeneous areas and have little if any interaction with the other religion. This segregation extends to education, such that even public schools are entirely Muslim or Christian. Ruhupatty said, "Muslim students went to Islamic schools, and Christian students went to Christian schools or even at state schools

\footnotetext{
${ }^{4}$ Focus Group Discussion at SMP Negeri 9 Lateri. March $16^{\text {th }} 2018$.

${ }^{5}$ Focus Group Discussion at SMP Negeri 9 Lateri. March $16^{\text {th }} 2018$.

${ }^{6}$ Focus Group Discussion at SMP Negeri 4 Salahutu. March $27^{\mathrm{h}} 2018$.
} 
which is situated at Muslim or Christian's area." ${ }^{7}$ The same motivation is also stated by a teacher from SMP Negeri 4 Salahutu: "during the conflict, we were forced to live separately. Christians are on the Christian side and Muslims are on the Muslim side. Before the conflict, there were some Christian teachers at SMP Negeri 4 Salahutu. Because of the conflicts, however, they were transferred to other schools. So, we initiated this school pela in order to bring Muslim students and Christian students into interaction and intercommunication with one another". ${ }^{8}$

The second motivation is to create friendships between the students and teachers of the two schools. "We want to develop awareness that we are brothers and sisters. Our local wisdoms teach us about sharing life, caring for each other, and having empathy for each other. 'Potong di kuku rasa di daging' means even if we cut our finger nails, we will feel the pain in the flesh. 'Ale rasa beta rasa' means that I feel what you feel and 'sagu salempeng dipatah dua' means that one piece of the sago, a staple of Maluku diet, can be shared. The basic meaning of all these proverbs is that everyone should share power, their burdens, and every aspect of life. Even though we have different religions, we have to take care of each other."

Being bound by a pela relation means that the two schools hold many activities together. Among the various programs, it is the religious celebrations that attract the attention of many people. According to one teacher, "Through religious celebration events, all people in Indonesia and around the world will know that the conflict in the past does not mean we must still fight each other. We have moved to make our lives better than before. This is the responsibility of all people who believe in God". ${ }^{9}$ There was a criticism that this togetherness was performed simply to create an impression of togetherness with no other more principled motivation. But such program did not stop at that. It was a start and one that is underlied by a motivation to work on building true and permanent reconciliation among people in the society which experienced social religious conflict in the past. It is a step forward in the process of healing the wounds of the past.

The wounds in the memories of everyone affected by the conflict in the Moluccas in 1999-2004 are not only those with direct experience of the conflict, but also for the new generation who did not experience it

\footnotetext{
${ }^{7}$ Interview with Mrs. Ruhupatty. March 2018

8 Interview with Mr. Muhammad Laga.

${ }^{9}$ Interview with Mr. Muhammad Laga, at SMP Negeri 4 Salahutu.
} 
and have only heard the stories of the conflict. They are very much aware of the conflict, since its traces are still around them-for example, many victims of the conflict were buried in yard of houses, especially in places like Latery. The new generation may be manipulated by those who do not want to reconcile with others. Thus, activities through which the new generation meet and talk to each others are significant for healing the wounds of the past (Rambo, 2017).

The students create their own history by crossing borders to meet and talk to the others. They are creating a society to be a home where all people share their life and story, where there is no domination or tendency to control others, and everyone has a space to speak and to be heard. These students are able to write their own new history through the help of their teachers and through the training they receive from the schools to learn to examine, in a critical way, whether information is true or false, and to determine how to act for the good of all. The programs of the school pela build connections among students and open up opportunities for deeper conversations as they go camping or playing sports together.

The students, who only had activities exclusively in their school and with their classmates of the same religion, now have the opportunity to meet and do activities with other students from another schools and villages. Students from either school are able to cross the social and religious borders that have long separated them from the others. Some students say that we know the character and attitude of our pela schools brothers-sisters. Although the time allotted to pela activities is limited, the schools encourage students to become friends. Some tell us that they continue to communicate with their pela brothers-sisters on a regular basis through social media, by simply asking about daily activities and sharing what they do at school. "I just ask what he is doing". 10 "I text my friend to know what she did at school that day". ${ }^{11}$ "We ask them to visit us in the Christmas time". ${ }^{12}$ "During camping, we played games together; so we were very happy. We want to have activities together like this again". ${ }^{13}$ "We will still keep this relation alive even after we graduate from junior high school." 14 Asking about another person's daily life is a way of showing attention and caring to others. For junior-high

${ }^{10}$ Focus Group Discussion with students at SMP Negri 4 Salahutu. March $27^{\text {th }} 2018$

11 Focus Group Discussion with students at SMP Negeri 9 Lateri. March $16^{\text {th }} 2018$.

12 Focus Group Discussion with students at SMP Negri 9 Lateri. March $16^{\text {th }} 2018$.

${ }^{13}$ Focus Group Discussion with students at SMP Negeri 4 Salahutu, March $27^{\text {th }} 2018$.

${ }^{14}$ Focus Group Discussion with students at SMP Negeri 4 Salahutu, March $27^{\text {th }} 2018$. 
students, aged 14-16 years old, attention is a sign of openness to make friends. Generally, teenagers are more comfortable speaking with those of their age-peers. In a society that had been through serious social conflict causing settlement segregation, friendship among the young generation is very important and needed. Quoting Hanna Arendt, Aaron Schutz and Marie G. Sandy wrote "friendship is actually the bond of communities. When friend become equal partners, they learn how and in what specific articulateness the common world appears to the other, who as a person is forever unequal or different". (Schutz and Sandy 2015, 29)

The programs of the pela schools constitute a new atmosphere in the inter-religious dialogue that goes beyond what is commonly performed by theologians or religious leaders. Everyone who is interested in peace and reconciliation, including the young generation in junior high school, should be able to enter into religious dialogue. The dialogue between schools through the pela is a prime example of a grass-root, non-elite, dialogue (Schumann, 2008: xi). Both Muslim and Christian students learn when they have to speak and when they have to listen.

A cross-religious contact and communication leads to positive insights about the other religion. Firstly, the students of the pela schools are able to overcome their suspicions and fears when they meet and talk with people from other religions. Overcoming such suspicious and fear is hard work both at a personal and communal level. Secondly, the students of the school pela are ready to face and even embrace unexpected conditions. Students from both schools, by having the pela alliance, take a bold step moving outside their homogeneous safety zone.

\section{Transformative Pedagogy: Learning by Practicing}

The Indonesian government requires public school to offer classes on the subject of "Religious Education", with its curriculum prepared by the national committee of education. With few exceptions, the curriculum follows the mono-religious model, which offers almost no contact or exposure to other religious communities. This curriculum is implemented exclusively for each religion in its own classroom. Therefore, students would just study their own religious aspects without dealing with common issues concerning living together in a pluralistic society. Teachers of religion would prepare their teaching materials mainly for their own exclusive classrooms (Christianity for Christians; Islam for Muslims). In other words, the curriculum reduces inter-faith communication among 
Christian and Muslim students in most public schools, during post-conflict era in Ambon, creating the so-called segregated religious consciousness. As we know, the Indonesian 2013 Junior High School Curriculum considers teaching the respect of others as an aspect of attitude, while the 2006 curriculum defines respect for others as the aspect of character. ${ }^{15}$ This means that in the all learning processes, students are taught to have good intellectual abilities as well as good character. By such an exclusive design of religious education, however, even the school cannot get spaces to examine how the character of religious values are implemented in a pluralistic arena. The school community tends to isolate themselves from the realities of their given community.

On the contrary, the pela schools challenge such segregation in teaching religious courses in the public schools. For instance, a course can use the pela ritual as a space to teach certain religious themes. The students and teacher can share their reflections on how to live together using values from their religion and values from practice of pela. The unique atmosphere of that classroom encounter is based on friendship and brotherhood-sisterhood. By maintain this dynamic, the positive energy will flow.

The teachers, students and staff of both schools initiated to step beyond religious identity borderlines that have kept them stuck in their own exclusive religious spheres. As teachers state:

\footnotetext{
"We teach about good relationships among human beings. Even though, in fact, there are many differences between these two religions, God asks us to have compassion for one another. To be sure, the prime mission of Christians is to love others. The implementation of this mission can be recognized clearly on the pela relationship between SMP Negeri 4 Salahutu and SMP Negeri 9 Lateri." 16
}

"We teach students to have good relationship among human beings. God tells us to have good relationship with all men/women without any categories, including religion." 17

Loving and respecting one another is the essence of pela relationships. Such a deeper meaning of pela affects these schools as they use pela as a model to move forward towards a new kind of human relationship among students who come from different religious backgrounds. These

15 Konsep dan Implementasi Kurikulum 2013 - Paparan Wakil Menteri Pendidikan dan Kebudayaan RI Bidang Pendidikan. Kementerian Pendidikan dan Kebudayaan. Jakarta: 14 Januari 2014.

${ }^{16}$ Interview with Mrs. Henny Liklikwatil. March 2018.

${ }^{17}$ Interview with Mr. Cecep. March 2018 
schools utilize Maluku's local wisdom of pela as a contextual medium for the practical learning process of religious education. Nevertheless, this pela model between two schools brings about a new perspective on seeing and embracing others as friends.

Both schools acknowledged the positive influence of school pela model for the content of Religious Education. As a teacher says,

"In the curriculum of the $9^{\text {th }}$ grade, we have a topic about pluralistic society. Based on this topic, we teach students that they cannot avoid living in a pluralistic society. The fact of a pluralistic society is that we are different religiously and culturally, but we are one as the human being. Thus differences within the pluralistic society must not be used as reason to deny each other. The differences in religious life and cultural life shall not separate people. All we are one."

In addition, she says:

"In $7^{\text {th }}$ grade, there is a topic about solidarity in a pluralistic society. We teach students to respect one another even though we are different religiously and culturally. Especially in Christianity, Jesus Christ teaches us to respect one another, to be compassionate to one another, even to love those who hate us". ${ }^{18}$

So, this pela relationship between two schools in Lateri and Liang helps students to gain real experience about loving each other and crossing religious boundaries. Precisely, the impact of the school pela to the Christian Education is that the students experiencing a real compassion with people from another religion, which is a main notion in Christianity. Christianity also teaches its followers to respect others, including strangers (Valkenberg 2006:9). In this regard, Islamic education features similar meaning with the Christian education. For instance, the value of respect and kindness which a part of Islamic religious teachings. Thus, to be sure, the pela schools have a great influence in transforming the perspective of students as well as helping them develop compassion and solidarity as an integral part of their personal life.

Compassion and solidarity are usually understood as the ability to let oneself to take actions to help others. Compassion drives students towards having awareness that as God's creation, the lives of other people have worth; so they have to protect the life of all human beings regardless their backgrounds or identities. Glorifying God Almighty means to honour human dignity. Compassionate students will be committed to

${ }^{18}$ Interview with Mrs. Henny Liklikwatil. March 2018 
demonstrating inclusive solidarity to other people in order to respect human dignity. In other words, compassion will enable students not to see others as objects or to treat others with violence.

Moreover, all schools in Ambon require every student to study a special, compulsory subject entitled Pendidikan Orang Basudara or Brotherhood-Sisterhood Education. That curriculum is designed to help students honour each other in the context of pluralism in Ambon. This is an example of how the Indonesian education system provides each region the opportunity to develop local curricula to meet local needs. The relation between Pendidikan Orang Basudara and school pela is that pela is a form of brotherhood-sisterhood. In the past, the pela bond was a pact that established a connection between villages. It was part of the societal system. Now, in the post conflict period, the schools employ pela to be a common ground that builds a brotherhood-sisterhood relation between Muslims and Christians. At the same time, Pendidikan Orang Basudara was suggested by educational stakeholder in Ambon municipality as a new way of seeing what education should look like in post conflict time. Pendidikan Orang Basudara is based on the curriculum that utilizes the local wisdom of Maluku people. School pela can be seen as form of Pendidikan Orang Basudara.

All activities conducted by pela schools aim at bringing new understandings of religion and of human existence. The way of thinking of Christian and Muslim students who participate in Islamic and Christian festival is both challenged and transformed.

The practice of pela schools creates a new kind of school in the Maluku context. It embodies an important aspect of its society. This remodelling process at the same time will have an impact on the society. In other words, it is a dialectical process of education. The school then positions itself not only as a micro-society but also as the society itself.

Students learn to recognize that, as religious people, Muslims and Christians have their own convictions that should be recognized and respected. Moreover, pela schools are committed to promoting a respectful attitude toward the religions of their brothers-sisters. Participation in other religious celebrations teaches students about respecting and honouring the others, but it does not mean that they are abandoning their own religion. They learn that respecting others means more than just not disturbing others. As a teacher at SMP Negeri 9 Lateri explains, it means taking part in the joy and happiness of their brothers and sisters' religious festivals (Iwamony, 2010:170). While for a teacher at SMP Negeri 4 
Salahutu, "Taking part in Christmas celebrations is a way of showing our respect and awareness that differences of our religion does not mean that we have to fight each other."19

Singing other religious songs and wearing other religious clothes, even taking part in the holiday celebrations, as the students of the pela schools do, have been interpreted in more than one way. On the positive side, some people argue that it is a demonstration of a kind of religious tolerance. On the negative side, others argue that it is an expression of losing one's own religious faith. Singing and wearing the Muslim women's head scarf are some of the ways to understand and to see how those songs and garments touch the lives of the practitioners. Those practices take us to the deeper meanings of religious tolerance. The religious tolerance, in this case, means the ability of human beings to be free both for inward and 3 tward. Fran Furedi (2019) says that:

\begin{abstract}
Without tolerance we cannot be free, we cannot live with one another in relative peace, we cannot follow and act on our conscience, we cannot exercise our mora 3 utonomy, and we cannot pursue our own road towards seeking the truth. Tolerance represents a positive orientation towards creating the conditions where people can develop their autonomy through the freedom to choose.
\end{abstract}

In the context of a diverse society, these practices help people to form or be formed into open-minded people.

Another aspect of that tolerance is that students thought the pela relationship become a way to see religious segregation. It has stimulated them to see that brotherhood-sisterhood point of view to deal with religious diversity. Another religion is their brother-sister religion. From this point of view, the relationship is more fluid and makes the border more porous.

By taking part in the school pela programs students can learn that differences in every religion are the richness of life. This is the outcome of that practice. Instead of treating differences as a threat, students develop the understanding that religious differences are not without hope for unity among religious people. Some students assert, "We can learn positive values from our Muslim students". ${ }^{20}$ By doing this, Christian and Muslim students come into awareness that differences among religions are not a threat. In contrast, religious differences teach them to be aware of the limitation of human beings to understand the work

\footnotetext{
${ }^{19}$ Interview with Mrs. Lona Parinussa at SMP Negeri 9 Lateri. March 2018

${ }^{20}$ Focus Group Discussion with students at SMP Negeri 9 Lateri. March $16^{\text {th }} 2018$.
} 
of the Almighty God. God and God's words are greater than what religions can describe through their dogma and religious practices. In other words, religious differences challenge people to open their minds to see that they need one another. Therefore, differences in religious life should be recognized and accepted as a natural gift from within the religion itself rather than seeing those differences as walls that separate and discriminate people.

Moreover, the pela schools attempt to reconcile religious differences through religious celebration events. Here, reconciliation means Muslim and Christians have to recognize each different point of view and not use those differences to reject and deny contact and activities with each other. An example of reconciliation of religious differences performed by the pela schools can be seen in the religious celebrations. In Islam, it is prohibited for Muslims to eat food considered haram, while in Christianity there is no such category. In the spirit of the pela, SMP Negeri 9 Lateri provides a special meal table for their Muslim brothers-sisters from SMP Negeri 4 Salahutu. In turn the Muslim students do not refuse to join in the meal in the Christians' religious celebration because they trust that their Christian brothers-sisters will ensure that the menu is in accordance to the Islamic teachings. The same kind of religious reconciliation takes place when they plan a camping trip as part of their shared pathfinder program. SMP Negeri 4 Salahutu is in charge of preparing meals. "It is a way to cope up with our religious differences," said a teacher. This is a kind of true religious reconciliation.

Nevertheless, having formed a pela does not keep these two schools from criticizing each other or having difficult discussions. In the frame of the pela, expressing disappointment is an evidence that they understand each other very well. Just as in family life, brothers and sisters may argue and still come to a good and positive decision about something. Pela schools also can develop a relationship of trust in which they can even discuss religious fundamentalism that is nowadays a serious problem in pluralistic society in the global context.

\section{Transforming the Meaning of Formal School}

In terms of inclusive religious education, the pela schools have shown a unique phenomenon into a formal education setting. In this section, we would like to discuss some descriptions that point to this phenomenon. It can be a transformative practice. 
In the Indonesia context, formal schools have been shaped by modern theories and applications. The model of learning, all aspects of curriculum, structure, human relation pattern, model of evaluation, etc. follows the modern school paradigm. The modern school paradigm is an understanding of curriculum as something measurable, developed in a certain system and linear logic. In that setting, the schools teach the traditional customs as merely an object of study. Therefore, the students learn it as part of "head" knowledge only. It would somehow position them as outsiders. There is a gap between adat or traditional custom and the culture of school.

There is a transformative process in the practice of pela schools where the schools are the main actors of pela. They learn by practicing it. They embody that custom. Actually, this is a rare experience! The whole curriculum such as initiative, planning, implementation and evaluation take a breakthrough position over the total existence of the formal school. They practice multi-models such as discovery model and cooperative model. The methods implemented also practice the traditional customs in the modern form of education.

In other words, a pela school's curriculum is influenced by the practice of pela in society. The society becomes the main educator for teaching what and how inclusive religious education actually is. The practices in society become an alternative pattern due to their wide history and actualization. Regardless of the funding issue, educational mechanism through the school pela practices stimulates educational system rethinking. Religious education should not be seen as a mere for-profit corporation or determined by huge money. Therefore, the inclusive religious education does not always need stakeholders with big money as its condition. It is primarily about the interactive process within the school's management and, we hope, driven by the so-called snow-ball effect, the atmosphere of education will be influenced by the process.

It takes time to see how the pela schools relationship works by showing its domino effect to the open society. Nevertheless, so far the practice of pela schools among young students, teachers and staff has suggested a new concept of education. That is, that formal education does not have to be based only on the conventional modern approach. Beside its reconciliatory functions, this practice of pela-school also contributes to the transformation of formal education. 


\section{CONCLUSIONS}

This research project attempts to observe the employment of the traditional practice of pe 2 alliances in Muslim and Christian communities in Central Maluku by SMP Negeri 9 Lateri and SMP Negeri 4 Salahutu on Ambon Island. Each school has a homogenous composition of students and teachers: SMP Lateri is predominantly Christian students, teachers and staffs, whereas SMP Salahutu are Muslims. They both have experienced the trauma of socio-religious conflict in Ambon between 1999-2004 and feel the conflict was destructive to the social mentality and disruptive to the educational activities for teenagers in Maluku. Therefore, teachers and students of both schools initiated a reconciliation covenant and constituted a new kind of pela alliance between two junior high schools. The meaning of traditional pela alliances-as covenantal inter-communities cultural alliances between those from different religious backgrounds-nowadays is given a contextual meaning as a model for inter-religious relation and communication through educational institutions in Ambon.

The school pela experimentation is an important breakthrough to introduce peace education. Peace education is not only concepts or theories but rather about common inter-religious communal practices. Peace Education is a multidisciplinary approach to embrace participatory nonviolent processes that aims to prevent any form of violence. promote respect of human rights and aid the maintenance of nonviolent human interaction by educating people according to cognition, attitude and skill. (Besseling 2014, 38-43) There is no an easy way to do it. Therefore, it needs common works and positive thinking that should be continuously embedded as educative values through systematic and practical learning programs. The 2013 national curriculum still has room for segregated consciousness on religious differences so it needs to be properly rethought and reformulated to embedding multiculturalism consciousness in the quotidian interactions of teenagers in Ambon.

We can draw several paradigms from this discussion:

- The basic assumption of the inclusive religious education program inspired by school pela practice is that humanity needs brother/sisterhood which can be constructed to overcome differences and hostility. Education should be a peaceful and harmonious cultural mirror.

- The dominant value of this practice is the background of existence and function of pela schools which are complementary and have a mutual respect relationship. 
- The model that might be developed is a praxis model which links ideas, commitments, and practices of pela schools.

- The issue to be responded to is the effect of conflict culture, religious fanaticism, and exclusive religious education.

- The key concepts which operationalized in this, for instance: pela, safe space, education, fellowship, inclusive religiosity, and respecting others.

- Methods which evolve are cooperation and cross-border collaboration, sharing of experiences (inductive), performances, and practices.

The pela between schools may work very well in Maluku because the people already understand the spirit of pela in its traditional sense. However, it does not mean that it cannot work outside the traditional ways and be implemented beyond the particularity of the Maluku peoples' cultural context. The core spirit of the pela is the commitment to stepping out of one's own religious and cultural boundaries in order to meet and to share life with others as "universal" brothers-sisters. This experimentation in peace building on the basis of local cultural values or local wisdom might be shared with many other Indonesian and international communities.

\section{BIBLIOGRAPHY}

Amirrachman, Alpha (ed.). 2007. Revitalisasi Kearifan Lokal:Studi Resolusi Konflik di Kalimantan Barat, Maluku dan Posso, ICIP-EIDHR, Jakarta.

Amirrachman, Alpha. 2012. Peace Education in the Moluccas, Indonesia: Between Global Models and Local Interests. Dissertation: Universiteit van Amsterdam.

Bartels, Dieter. 1977. Guarding The Invisible Mountain: Intervillage Alliancees, Religious Syncretism and Ethnic Identity among Ambonese Christians and Moslems in the Moluccas. Dissertation: Comell University, Ithaca.

Besseling, Roderick (eds.). 2014. Mainstreaming Peace Education - Methodologies, Approaches and Visions: A Practitioner's Manual, European Intercultural Forum.

Cooley Frank. 1962. Ambonesse Adat: A General Description New Haven, Conn: Yale University, South East Studies, Cultural Report Series No. 10, 1962

Furedi, Fran. 2019. On Tolerance: In Defence of Moral Independence. Essay based on the speech 'Freedom of Speech: The Case for Tolerance' at The Centre for Independent Studies in Melbourne in 2011. 
https://www.cis.org.au/app/uploads/2015/04/images/stories/policymagazine/2012-winter/28-2-12-frank-furedi.pdf, January, 21, 2019.

Gaspersz, Steve G. C. 2016. Negotiating Religious Identities, Cultural Authorities and Modernity in Leihitu, Ambon Island. Dissertation: Universitas Gadjah Mada, Yogyakarta.

Iwamony, Rachel. 2010. The Reconciliatory Potential of the Pela in the Moluccas. Dissertation: Vrije Universiteit Amsterdam.

MacIntyre, Alasdair. 1981. After Virtue. Notre Dame: University of Notre Dame Press.

Rambo, Shelly. 2017. Resurrecting Wounds: Living in the Afterlife of Trauma, Baylor University Press: Waco,Texas.

Ruhulessin, John Chr. 2005. Etika Publik: Menggali dari Tradisi Pela di Maluku. Dissertation : Universitas Kristen Satya Wacana.

Schutz, Aaron and Sandy Marie G. 2015. "Friendship And The Public Stage: Revisiting Hanna Arendt's Resistence To Political Education." Educational Theory, Volume 65, Number 1, 2015.

Souisa, Nancy Novitra. 2017. Makan Patita: Nilai dan Maknanya dalam Membangun Pendidikan Kristiani yang Kontekstual. Dissertation: Universitas Kristen Satya Wacana.

Schumann, Olaff, Dialog Antarumat Beragama: Membuka Babak Baru dalam Hubungan Antarumat Beragama. BPK Gunung Mulia, Jakarta 2008. Agama-Agama: Kekerasan dan Perdamaian. BPK Gunung Mulia, Jakarta 2011.

Valkenberg, Pim, 2006. Sharing Lights on the Way to God: Muslim-Christian Dialogue and Theology in the Context of Abrahamic Partnership. Amsterdam-New York, Rodopi. 
Cek 2

ORIGINALITY REPORT

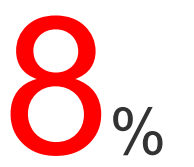

SIMILARITY INDEX

\section{$8 \%$}

INTERNET SOURCES
$0 \%$

PUBLICATIONS

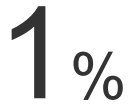

STUDENT PAPERS

PRIMARY SOURCES

1 hdl.handle.net

Internet Source

2 poj.peeters-leuven.be

Internet Source

3\%

3 www.cis.org.au

Internet Source

$\begin{array}{llll}\text { Exclude quotes } & \text { On } & \text { Exclude matches } & <1 \% \\ \text { Exclude bibliography } & \text { On } & \end{array}$

